\title{
Cockayne Syndrome with Delayed Recovery of RNA Synthesis after Ultraviolet Irradiation but Normal Ultraviolet Survival
}

\author{
KATSUO SUGITA, NOBUO SUZUKI, TAKAYUKI KOJIMA, YUZO TANABE, \\ HIRONORI NAKAJIMA, AKIKO HAYASHI, AND MASATAKA ARIMA \\ Departments of Pediatrics [K.S., Y.T., H.N.], Biochemistry [N.S.], and Dermatology [T.K.], Chiba University \\ School of Medicine, Chiba, and Division of Mental Retardation and Birth Defect Research [A.H., M.A.], \\ National Center for Nervous, Mental and Muscular Disorders, Tokyo, Japan
}

\begin{abstract}
We report a girl with Cockayne syndrome (CS) with atypical cellular features. We studied the ultraviolet (UV)-sensitivity of cultured fibroblast cells derived from this case and male CS siblings as positive controls. Cells from this female with CS displayed normal unscheduled DNA synthesis and repair replication capacity. However, the cells also displayed a less depressed level of RNA synthesis after UV irradiation, compared to control CS cells, and showed normal UV survival. This CS case with early onset of abnormalities had more serious clinical manifestations than the control CS siblings. These cytological results suggest that there is considerable clinical and cellular heterogeneity in CS and that cellular sensitivity to UV might not be as essential for the diagnosis of CS as previously thought. (Pediatr Res 21: 34-37, 1986)
\end{abstract}

\section{Abbreviations}

UV, ultraviolet

UDS, unscheduled DNA synthesis

CS, Cockayne syndrome

$\mathrm{XP}$, xeroderma pigmentosum

T3, triiodothyronine

T4, thyroxine

TSH, thyroid stimulating hormone

CT, computed tomography

$\mathrm{CF}$, colony formation

TCA, trichloroacetic acid

PBS, phosphate-buffered saline

CS, a rare autosomal recessive disorder, was first described in 1936 (1), and a diagnosis is made clinically on the basis of cachectic dwarfism, deafness, cataracts, retinal pigmentation, photosensitivity, a thickened skull, intracranial calcification, mental deficiency, and characteristic facial features $(2,3)$. In addition to these findings, cells derived from CS patients have been shown to be highly sensitive to UV-killing, and the detection of high UV-sensitivity has been considered to be essential for the diagnosis of this syndrome (4). Andrews et al. (5) have suggested a correlation between the clinical severity of the degenerative neuron system and the cellular DNA repair after UV irradiation in XP, which is another UV-sensitive disease. However, their exact relationship remains controversial in XP and CS. It is

Received December 31, 1985; accepted August 11, 1986.

Correspondence address Katsuo Sugita, Department of Pediatrics, Chiba Unversity School of Medicine, 1-8-1 Inohana, Chiba-shi, Chiba, Japan 280. therefore important for comparative studies to be performed whenever both clinical and cytological data are available, especially for cases with atypical manifestations or unusual cellular sensitivity to UV. We recently had the opportunity to observe a girl with CS whose fibroblast cells showed normal sensitivity to UV light. We further examined cells from this female with CS and two CS siblings for comparison, as to sensitivity to x-rays, UV-induced UDS, repair replication, and total cellular DNA or RNA synthesis after UV irradiation. The purpose of this study is to clarify whether or not these biochemical defects parallel the severity of the clinical manifestations, particularly that of the neurological deterioration.

\section{CASE REPORTS}

Case 1. K.K. was born without complications after a full-term, noncomplicated gestation with a birth weight of $2.6 \mathrm{~kg}$. There was no family history of consanguinity, congenital disease, mental retardation, or movement disorders. She was a poor feeder from birth, and growth failure persisted. She could support her head at 6 months when delayed acquirement of motor milestones became evident. She sat at 12 months of age, crawled at 24 months, and stood with support at 4 yr of age. She could walk with support until about 6 yr but her gait was broad-based and ataxic. Because of an increasing gait disorder and joint contractures, she remained in bed almost exclusively from 9 yr of age.

On physical examination at $14 \mathrm{yr}$ old, she was small with sunken eyes, a beak-like nose, and a projected maxilla (Fig. 1). Her height was $115 \mathrm{~cm}$, weight $17 \mathrm{~kg}$, and head circumference $44.5 \mathrm{~cm}$. Her mental status was severely retarded and she could not say any meaningful words. She was not unduly sensitive to sunlight. She had small breasts and little pubic hair, and the menarche had not occurred at that time. There were coarse resting tremors in both hands, which increased with intention. Ophthalmological examination revealed retinitis pigmentosa, optic atrophy, and cataracts.

Normal laboratory test results included those for complete blood counts, serum electrolytes, growth hormone, T3, T4, TSH, plasma cortisol, serum copper and ceruloplasmin, urine copper, heavy metals, amino acids, urinary arylsulfatase $\mathrm{A}$, and chromosome studies. Skull radiograms showed thickening of the calvarium. Cranial CT revealed marked enlargement of the entire ventricular system with cortical atrophy but no intracranial calcification. At $16 \mathrm{yr}$ of age she died of aspiration pneumonia at home but an autopsy could not be performed.

Cases 2 and 3. K.Ki and T.Ki. were male siblings with typical CS cases and were not related to case 1. They were described previously (6). In brief, they were considered normal for the 1st $\mathrm{yr}$ of life, but delayed acquirement of motor milestones became 


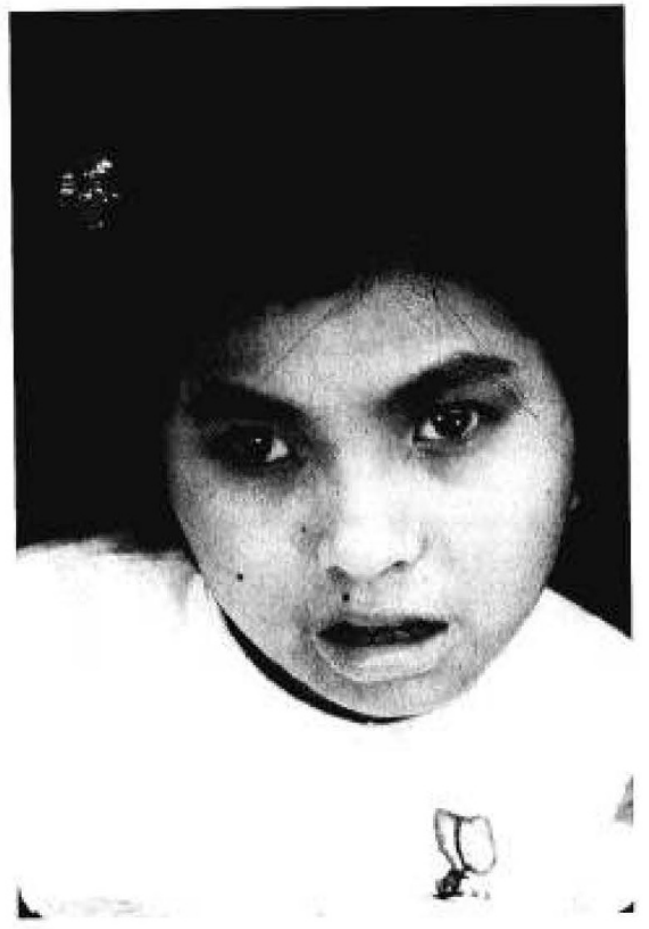

Fig. 1. Facial appearance of case 1.

evident from then onward. Both showed the characteristic features of microcephaly, a short stature, mental retardation, retinitis pigmentosa, photosensitive skin, and deafness. CT scanning revealed calcification in the bilateral basal ganglia. Their faces were similar in appearance to that of case 1 . Using standard Gand R-banding techniques, peripheral blood lymphocytes revealed normal karyotypes in these siblings as in case 1 . Cell strains derived from these cases were included in this cytological study for comparison with case 1 .

\section{METHODS}

Cell culture. Normal cell strains (AK and $\mathrm{YO}$ ) (7) and the three CS cell lines (CCS1, 2, and 3) from cases 1, 2, and 3, respectively, were included in this study along with two excisiondefective XP cell lines (XP24TO) (7) and (XP1KY) (8) and one ataxia telangiectasia cell line (GM2052) (9). XP24TO and XP1KY fibroblasts were provided by Y. Suzuki, the Department of Biochemistry, Tokyo Medical and Dental University, Tokyo, Japan and H. Takebe, Radiation Biology Center, Kyoto University, Kyoto, Japan, respectively. GM2052 cells were obtained from the Institute of Medical Research, Camden, NJ. All cell lines were grown in Dulbecco's modified Eagle's medium (Grand Island Biological Co., Grand Island, NY) supplemented with $10 \%$ fetal calf serum (Flow Laboratories, Rockville, MD), 100 $\mu \mathrm{g}$ streptomycin $/ \mathrm{ml}$, and $100 \mathrm{U}$ penicillin $\mathrm{G} / \mathrm{ml}$ at $37^{\circ} \mathrm{C}$ in a humidified atmosphere containing $5 \% \mathrm{CO}_{2}$. At the time of the experiment, the fibroblasts were between the $3 \mathrm{rd}$ and 12 th passage levels in vitro.

Cellular sensitivities to $U V$ and $x$-rays. UV and $\mathrm{x}$-ray sensitivity tests involving CF assays were performed essentially as previously described $(9,10)$. Cells, $1.5 \times 10^{3}$, of each fibroblast cell strain were seeded in a $100-\mathrm{mm}$ culture dish (Nunc, Roskilde, Denmark) followed by UV or x-ray irradiation. The survival percentage ratios (counts of colonies in a test dish/counts of colonies in a control dish) were determined.

Total cellular DNA and RNA syntheses. Total cellular DNA synthesis was measured by a pulse-labeling method, as previously described (10). Briefly, logarithmically growing cells were cultured with $0.02 \mu \mathrm{Ci} / \mathrm{ml}\left[2-{ }^{14} \mathrm{C}\right] \mathrm{dThd}(50 \mathrm{mCi} / \mathrm{mmol}$, New England Nuclear, Boston, MA) for $24 \mathrm{~h}$. At $20 \mathrm{~h}$ after seeding of the prelabeled cells, the cells were irradiated with UV and then pulselabeled with $5 \mu \mathrm{Ci} / \mathrm{ml}$ [methyl- $\left.{ }^{3} \mathrm{H}\right]$ thymidine $\left(\left[{ }^{3} \mathrm{H}\right] \mathrm{dThd}\right)(62 \mathrm{Ci} /$ mmol, New England Nuclear) for $10 \mathrm{~min}$, followed by counting of the radioactivity in the TCA-insoluble cell materials. Total cellular RNA synthesis was also measured, using $\left.5 \mu \mathrm{Ci} / \mathrm{ml}{ }^{3} \mathrm{H}\right]$ uridine $\left(30 \mathrm{Ci} / \mathrm{mmol}\right.$, New England Nuclear) instead of the $\left[{ }^{3} \mathrm{H}\right]$ dThd used for DNA synthesis.

Unscheduled DNA synthesis. The technique of Robbins et al. (11) was mainly used to measure UDS. Cells were plated in single chamber Lab-Tek slides (Miles Scientific, Inc.) at a density of $5 \times 10^{4}$ cells per slide. After $24 \mathrm{~h},\left[{ }^{3} \mathrm{H}\right] \mathrm{dThd}(20 \mathrm{Ci} / \mathrm{mmol}$, New England Nuclear) was added to the growth medium $(5 \mu \mathrm{Ci}$ / $\mathrm{ml}$ ), and the incubation was continued for another $30 \mathrm{~min}$. The cultures were washed with PBS $(8.0 \mathrm{~g} \mathrm{NaCl}, 0.2 \mathrm{~g} \mathrm{KCl}, 1.15 \mathrm{~g}$ $\mathrm{Na}_{2} \mathrm{HPO}_{4}$ and $\mathrm{KH}_{2} \mathrm{PO}_{4}$ in 1 liter distilled $\mathrm{H}_{2} \mathrm{O}$ ) and then irradiated with UV. After washing twice with $\mathrm{PBS}$, serum-free growth medium containing $\left[{ }^{3} \mathrm{H}\right] \mathrm{dThd}(5 \mu \mathrm{Ci} / \mathrm{ml})$ was added for $120 \mathrm{~min}$. The slides were then coded, washed, fixed, and autographed.

Studies on repair replication. The UV-induced DNA repair replication was measured as previously described (10). Briefly, 1 $\times 10^{6}$ cells, mock-irradiated and irradiated at 15 and $30 \mathrm{~J} / \mathrm{m}^{2}$, were incubated for $3.5 \mathrm{~h}$ with $10 \mu \mathrm{Ci} / \mathrm{ml}\left[{ }^{3} \mathrm{H}\right] \mathrm{dThd}(20 \mathrm{Ci} / \mathrm{mmol}$, New England Nuclear) as the repair label. DNA was extracted from the cells, and then the parental density DNA fractions were isolated from neutral $\mathrm{CsCl}$ gradients, followed by centrifugation in alkaline ( $\mathrm{pH} 12.5) \mathrm{CsCl}$ gradients. The ratio of ${ }^{3} \mathrm{H}$ radioactivity to DNA was calculated by collecting the fractions of the parental DNA peaks and counting.

\section{RESULTS}

Sensitivity to $U V$ and $x$-rays. The ability of CCS 1 fibroblasts to form colonies after UV irradiation was very similar to that of normal controls, but distinct from those of the more UV-sensitive CCS2, CCS3, and XP24TO fibroblasts (Fig. 2). As to the colony-

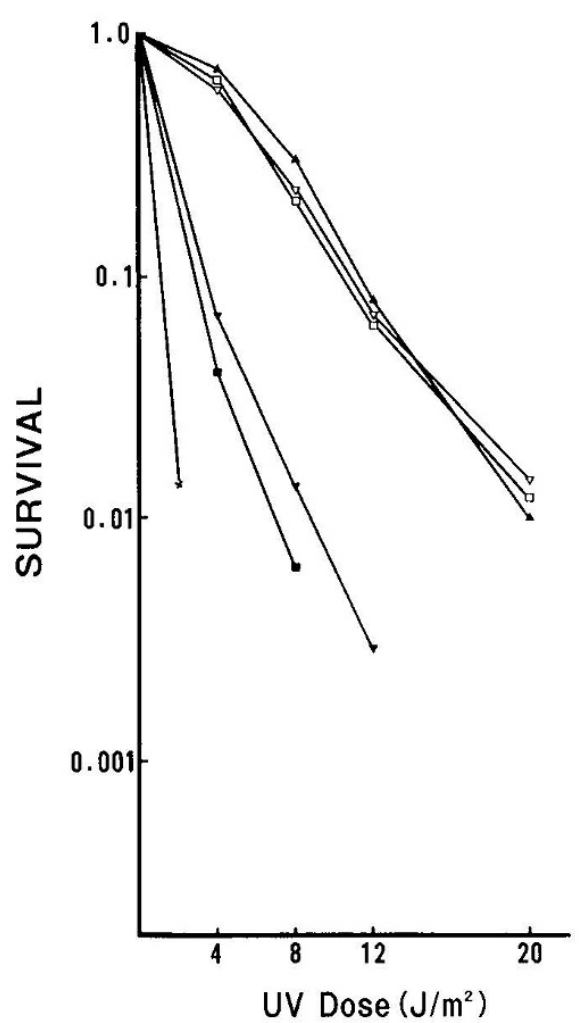

Fig. 2, UV survival curves for cells irradiated in the exponential growth phase. Fibroblasts from normal donors, AK $(\square)$, YO $(\nabla)$; index cases, CCS1 ( $\mathbf{\Delta}), \operatorname{CCS} 2(\boldsymbol{\bullet}), \operatorname{CCS} 3(\mathbf{\nabla})$; and XP24TO (x). 
forming ability after x-ray irradiation, the CCS1 strain, like the other two CS strains, showed no hypersensitivity in comparison to that of GM2052 cells (Fig. 3).

Total cellular DNA and RNA syntheses. Eight $\mathrm{J} / \mathrm{m}^{2}$ produced the initial depression in DNA and RNA syntheses in all cells studied (Figs. 4 and 5). The levels of $\left[{ }^{3} \mathrm{H}\right] \mathrm{dTh}$ incorporation into CCS1 and normal cells were elevated $2 \mathrm{~h}$ after UV irradiation and were significantly different from that of CCS2 and CCS3 cells 2,6 , and $10 \mathrm{~h}$ after UV irradiation. $\left[{ }^{3} \mathrm{H}\right]$ uridine incorporation into CCS1 cells, as in the cases of CCS2 and CCS3 cells, was more decreased than that into control cells during the first

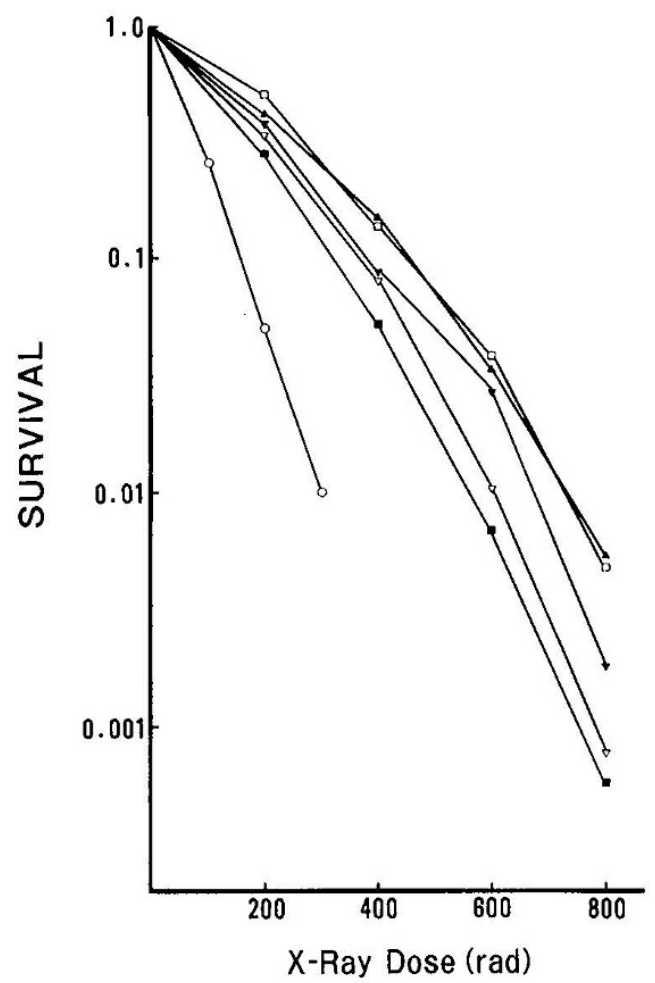

Fig. 3. X-ray survival curves for cells irradiated in the exponential growth phase. AK $(\square)$, YO $(\nabla), \operatorname{CCS} 1(\boldsymbol{\Delta}), \operatorname{CCS} 2(\boldsymbol{\nabla}), \operatorname{CCS} 3(\nabla)$, and GM2052 (O).

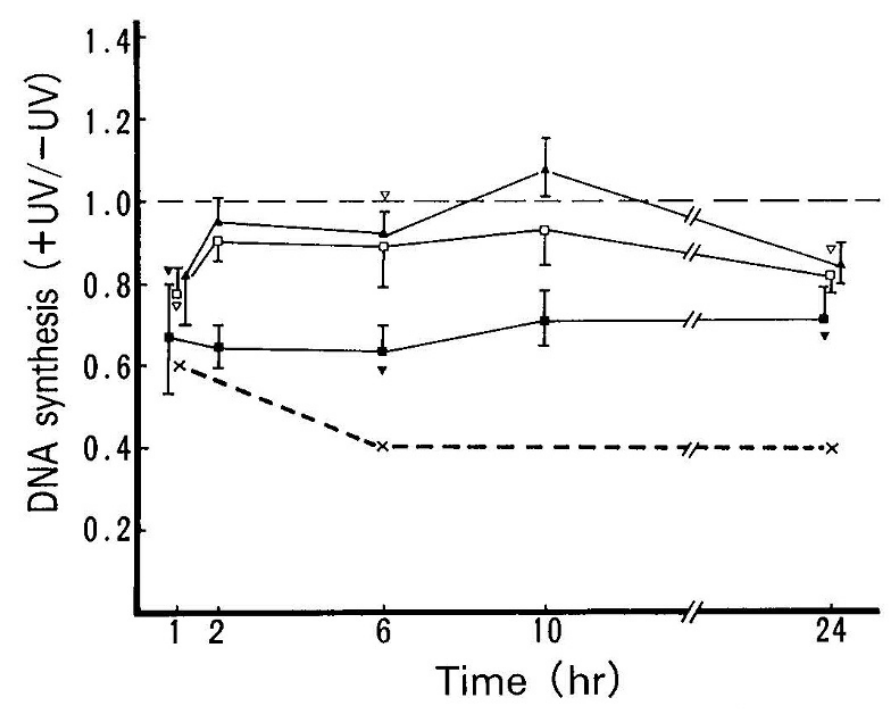

Fig. 4. Total cellular DNA synthesis activity after $8 \mathrm{~J} / \mathrm{m}^{2} \mathrm{UV}$ irradiation. Cells $\left(5 \times 10^{4}\right)$ prelabeled with $\left[{ }^{14} \mathrm{C}\right] \mathrm{dTh}$ were seeded in a $35-\mathrm{mm}$ dish, irradiated, and then pulse-labeled with $\left[{ }^{3} \mathrm{H}\right] \mathrm{dThd}$. AK $(\square), \mathrm{YO}(\nabla)$, $\operatorname{CCS} 1(\boldsymbol{\Delta}), \operatorname{CCS} 2(\boldsymbol{\bullet}), \operatorname{CCS} 3(\boldsymbol{\nabla})$, and XP24TO (x), Bars, SE.

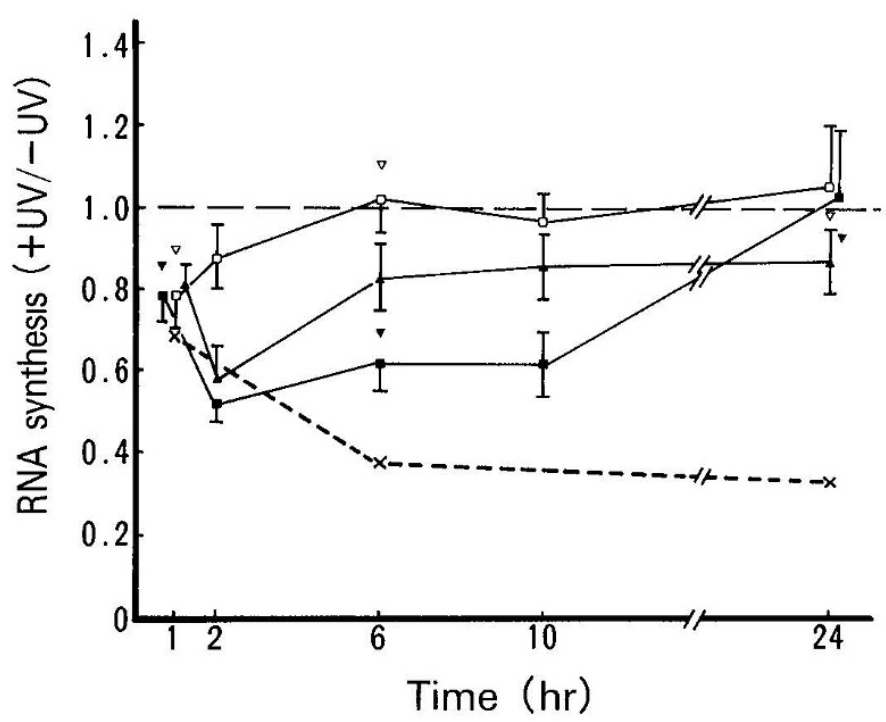

Fig. 5. Total cellular RNA synthesis activity after $8 \mathrm{~J} / \mathrm{m}^{2} \mathrm{UV}$ irradiation. Cells $\left(5 \times 10^{4}\right)$ prelabeled with $\left[{ }^{14} \mathrm{C}\right] \mathrm{dTh}$ were seeded in a $35-\mathrm{mm}$ dish, irradiated, and then pulse-labeled with $\left[{ }^{3} \mathrm{H}\right]$ uridine. AK ( $\square$ ), YO $(\nabla), \operatorname{CCS} 1(\boldsymbol{\Delta}), \operatorname{CCS} 2(\bullet), \operatorname{CCS} 3(\nabla)$, and XP24TO (x), Bars, SE.

$2 \mathrm{~h}$ after UV irradiation $\left(8 \mathrm{~J} / \mathrm{m}^{2}\right)$. However, recovery of RNA synthesis in CCS1 cells after UV irradiation was intermediate between that of normal controls and that of CCS 2 and CCS 3 cells. In these three CS strains, recovery of DNA and RNA syntheses was seen $24 \mathrm{~h}$ after irradiation when both nucleic acid syntheses in the XP24TO strain had still not recovered.

UDS. The UDS level after UV irradiation in CCS1 cells was similar to those in the control, CCS2 and CCS3 cells, in contrast with the low level in XP24TO cells (Fig. 6).

Repair replication. Quantitative measurement of the amounts of repair replication indicated that repair-proficient cells of AK, CCS1, CCS2, and CCS3 revealed high levels of repair replication synthesis, particularly at high dose of $\mathrm{UV}\left(30 \mathrm{~J} / \mathrm{m}^{2}\right)$ in comparison to cells of two XP strains.

\section{DISCUSSION}

The clinical symptoms of the three described cases agreed with major criteria of Sugarman et al. (2) except for the lack of intracranial calcification in case 1 . We further observed a typical facial features, ankylosis, optic atrophy, hypogonadism, and deterioration of the clinical course in case 1. Growth and development are normal during the 1st yr in typical CS, as in cases 2 and 3 , but in case 1 these disorders became manifest soon after birth and neurological deterioration progressed more rapidly. However, CS cases with early onset of manifestations have also been reported (12). The diagnosis of CS in case 1 is based primarily on the clinical findings as well as in cases 2 and 3 since no consistent biochemical abnormality has been discovered in CS.

Ordinarily, fibroblasts derived from CS cases are extremely sensitive to UV but not to $\mathrm{x}$-rays $(4,13)$, as judged by their colony-forming ability. However, there have been some reports of the cross-sensitivity of CS fibroblast strains to UV and x-rays $(14,15)$. A certain CS strain $(16)$ was shown to have the UV sensitivity that was intermediate between those in the published survival curves for normal and CS cells. These results suggest the broad spectrum of the sensitivity of CS cell strains to UV, but there has been no report of cell strains which had the same level of sensitivity to UV killing as normal cells. On the other hand, normal sensitivity to UV has been noticed in some fibroblasts derived from some cases of xeroderma pigmentosum (17), another UV-sensitive disease. Therefore, it may not be surprising if a CS cell line with normal UV survival is found. 


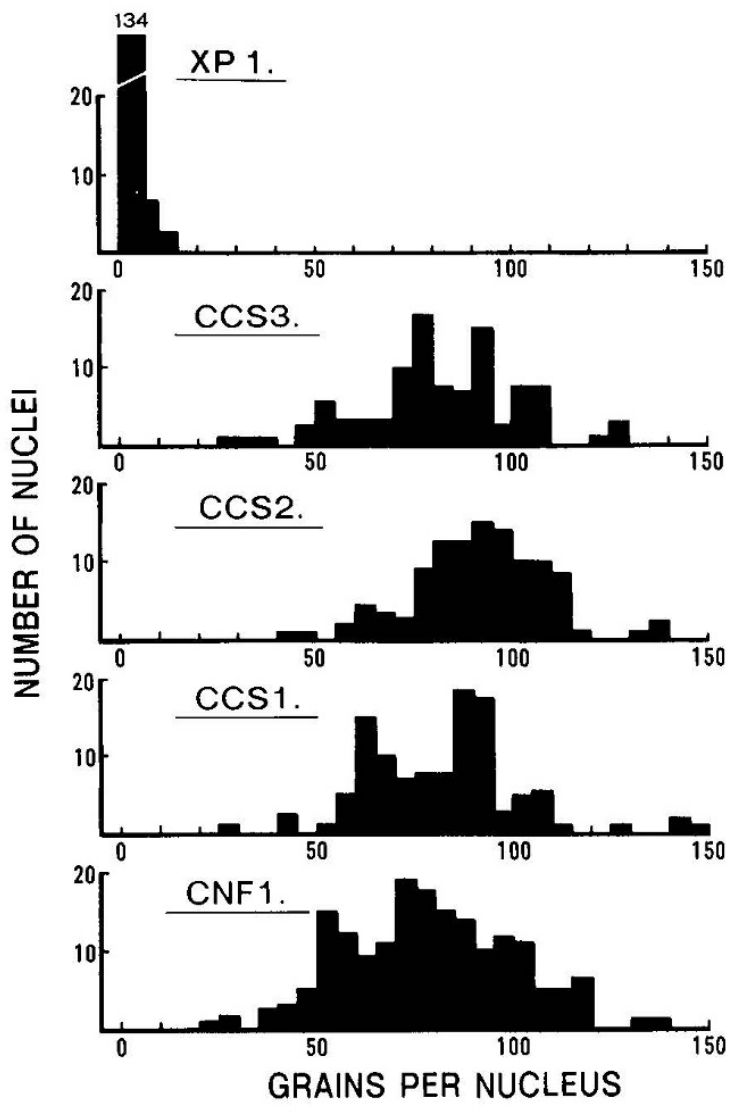

Fig. 6. Histograms of autographic data on $\left[{ }^{3} \mathrm{H}\right] \mathrm{dThd}$ incorporation into nuclei of fibroblasts after $20 \mathrm{~J} / \mathrm{m}^{2} \mathrm{UV}$ irradiation.

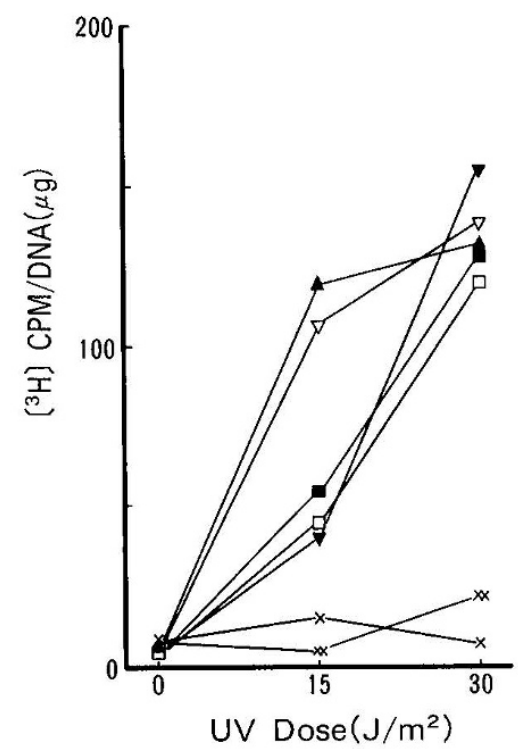

Fig. 7. Repair replication analysis on alkaline $\mathrm{CsCl}$ gradients of the parental density DNA from AK $(\square)$, YO $(\nabla), \operatorname{CCS} 1(\mathbf{\Delta}), \operatorname{CCS} 2(\boldsymbol{\bullet}), \operatorname{CCS} 3$ $(\mathbf{V})$ and XP24TO (x) and XPIKY (xx).

In general, the cellular level of nucleic acid synthesis after UV irradiation is a more sensitive indicator of UV-induced damage; for example, the above mentioned XP variant cells showed a slow recovery of DNA synthesis after UV irradiation (18). Mayne et al. (19) reported that the DNA or RNA synthesis capability of CS cells was also depressed after UV irradiation but that the level of depression was variable. They further suggested the possibility that there was some correlation between the level of nucleic acid synthesis and cell survival after UV irradiation in CS (19). In fact, we found that the level of total cellular DNA or RNA after UV irradiation was less depressed in CCS1 cells.

The molecular repair defect in CS has not been clarified although some complementation groups have been demonstrated $(20,21)$ (Fig. 7). The in vitro heterogeneity among CS cell strains might be due to a genetic difference at the loci responsible for this disease (21), and might reflect the broad spectrum of UV sensitivity shown by the ability of CF or nucleic acid synthesis after UV irradiation.

On the other hand, CS cases show a wide range of clinical severity and some CS cases with clinically atypical features have been reported $(22,23)$. Schmickel et al. (4) suggested that the cellular defects in CS might be ones in the repair of UV-induced damage. But we found that the level of UV sensitivity or the DNA repair defect did not parallel the severity of the clinical manifestations in case 1 . Therefore, it seems valid to state that there is considerable clinical and cellular heterogeneity in CS as there is in XP.

\section{REFERENCES}

1. Cockayne EA 1936 Dwarfism with retinal atrophy and deafness. Arch Dis Child 11:1-8

2. Sugarman GI, Landing BH, Reed WB 1977 Cockayne syndrome: clinical study of two patients and neuropathologic findings in one. Clin Pediatr 16:225232

3. Summitt RL 1979 Cockayne syndrome. In: Bergsma D (ed) Birth Defect Compendium, 2nd ed. Alan R. Liss Inc., New York, pp 236-237

4. Schmickel RD, Chu EHY, Trosko JE, Chang CC 1977 Cockayne syndrome: a cellular sensitivity to ultraviolet light. Pediatrics 60:135-139

5. Andrews AD, Barrett SF, Robbins JH 1976 Relation of DNA repair processes to pathological ageing of the nervous system in xeroderma pigmentosum. Lancet $1: 1318-1320$

6. Takayanagi T, Sanayama K, Masaoka J, Kinoshita M, Otake A, Niimi H, Naruse T 1981 Cockayne syndrome in siblings. Jpn J Pediatr 34:2415-2420

7. Kojima T, Fujita M, Okamoto S, Suzuki N 1985 Xeroderma pigmentosum variant. Nishinippon J Dermatol 47:1047-1052

8. Ishizaki K, Yagi T, Takebe H 1980 Cytotoxic effects of protease inhibitors on human cells. 1. High sensitivity of xeroderma pigmentosum cells to antipain. Cancer Lett 10:199-205

9. Hayashi A, Yoshida Y, Tanaka H, Arima M, Ohno K 1985 Variable radiosensitivity in fibroblasts from patients with tuberous sclerosis. J Invest Dermatol $84: 77-78$

10. Suzuki N, Nishimaki J, Kuwata T 1982 Characterization of a UV-resistant strain, UV'-10, established from a human clonal cell line, RSb, with high sensitivity to UV, 4NQO, MNNG and interferon. Mutat Res 106:357-376

11. Robbins JH, Kraemer KH, Lutzner MA, Festoff BW, Coon HG 1974 Xeroderma pigmentosum, an inherited disease with sun sensitivity, multiple cutaneous neoplasms, and abnormal DNA repair. Ann Intern Med 80:221248

12. Moyer DB, Marquis P, Shertzer ME, Burton BK 1982 Brief clinical report: Cockayne syndrome with early onset of manifestations. Am J Med Genet 13:225-230

13. Wade MH, Chu EHY 1979 Effects of DNA damaging agents on cultured fibroblasts derived from patients with Cockayne syndrome. Mutat Res 59:49-60

14. Chan GL, Little JB 1981 Cross-sensitivity of certain xeroderma pigmentosum and Cockayne syndrome fibroblast strains to both ionizing radiation and ultraviolet light. Mol Gen Genet 181:562-563

15. Deschavanne PJ, Diatloff-Zito C, Macieira-Coelho A, Malaise EP 1981 Unusual sensitivity of two Cockayne's syndrome cell strains to both UV and $\gamma$ irradiation. Mutat Res 91:403-406

16. Deschavanne PJ, Chavaudra N, Fertil B, Malaise EP 1984 Abnormal sensitivity of some Cockayne's syndrome cell strains to UV- and $\gamma$-rays, association with a reduced ability to repair potentially lethal damage. Mutat Res 131:6170

17. Cleaver JE 1972 Xeroderma pigmentosum: variants with normal DNA repair and normal sensitivity to ultraviolet light. J Invest Der 58:124-128

18. Cleaver, JE, Thomas GH, Park SD 1979 Xeroderma pigmentosum variants have a slow recovery of DNA synthesis after irradiation with ultraviolet light. Biochim Biophys Acta 564:122-131

19. Mayne LV, Lehmann AR 1982 Failure of RNA synthesis to recover after UV irradiation: an early defect in cells from individuals with Cockayne's syndrome and xeroderma pigmentosum. Cancer Res 42:1473-1478

20. Lehmann AR 1982 Three complementation groups in Cockayne syndrome. Mutat Res 106:347-356

21. Tanaka K, Kawai K, Kumahara Y, Ikenaga M, Okada Y 1981 Genetic complementation groups in Cockayne syndrome. Somat Cell Genet 7:445455

22. Kennedy RM, Rowe VD, Kepes JJ 1980 Cockayne syndrome: an atypical case. Neurology 30:1268-1272

23. Lanning M, Simila S 1970 Cockayne's syndrome, report of a case with normal intelligence. Z Kinderheilkd 109:70-75 